\title{
Leptin deficiency-induced obesity affects the density of mast cells in abdominal fat depots and lymph nodes in mice
}

Mehmet M Altintas', Behzad Nayer ${ }^{4}$, Eric C Walford ${ }^{1}$, Kevin B Johnson², Gabriel Gaidosh ${ }^{3}$, Jochen Reiser ${ }^{1}$, Nestor De La Cruz-Munoz ${ }^{5}$, Luis M Ortega ${ }^{1}$ and Ali Nayer ${ }^{1 *}$

\begin{abstract}
Background: Mast cells are implicated in the pathogenesis of obesity and insulin resistance. Here, we explored the effects of leptin deficiency-induced obesity on the density of mast cells in metabolic (abdominal fat depots, skeletal muscle, and liver) and lymphatic (abdominal lymph nodes, spleen, and thymus) organs. Fourteen-week-old male leptin-deficient ob/ob mice and their controls fed a standard chow were studied. Tissue sections were stained with toluidine blue to determine the density of mast cells. CD117/c-kit protein expression analysis was also carried out. Furthermore, mast cells containing immunoreactive tumor necrosis factor- $\alpha$ (TNF- $\alpha$ ), a proinflammatory cytokine involved in obesity-linked insulin resistance, were identified by immunostaining.
\end{abstract}

Results: ob/ob mice demonstrated adiposity and insulin resistance. In abdominal fat depots, mast cells were distributed differentially. While most prevalent in subcutaneous fat in controls, mast cells were most abundant in epididymal fat in ob/ob mice. Leptin deficiency-induced obesity was accompanied by a 20-fold increase in the density of mast cells in epididymal fat, but a 13-fold decrease in subcutaneous fat. This finding was confirmed by CD117/c-kit protein expression analysis. Furthermore, we found that a subset of mast cells in epididymal and subcutaneous fat were immunoreactive for TNF- $\alpha$. The proportion of mast cells immunoreactive for TNF- $\alpha$ was higher in epididymal than in subcutaneous fat in both ob/ob and control mice. Mast cells were also distributed differentially in retroperitoneal, mesenteric, and inguinal lymph nodes. In both ob/ob mice and lean controls, mast cells were more prevalent in retroperitoneal than in mesenteric and inguinal lymph nodes. Leptin deficiency-induced obesity was accompanied by increased mast cell density in all lymph node stations examined. No significant difference in the density of mast cells in skeletal muscle, liver, spleen, and thymus was noted between ob/ob and control mice.

Conclusions: This study demonstrates that leptin deficiency-induced obesity is accompanied by alterations in the density of mast cells in abdominal fat depots. The divergent distribution of mast cells in subcutaneous versus visceral fat might partially account for their differential biological behavior. Mast cells might also play a role in adaptive immune response occurring in regional lymph nodes in obesity.

Keywords: Obesity, leptin, mast cells, adipose tissue, inflammation

\section{Background}

Obesity has reached epidemic proportions in many parts of the world [1]. Obesity if often accompanied by a lowgrade systemic inflammatory state and adipose tissue inflammation [2]. Although the underlying mechanisms

\footnotetext{
* Correspondence: anayer@med.miami.edu

'Department of Medicine, Miller School of Medicine, University of Miami, Miami, FL, USA

Full list of author information is available at the end of the article
}

that induce adipose tissue inflammation in obesity remain largely elusive, adipocyte injury and death appear to play a central role [3]. Cells and mediators of both innate and adaptive immunity are involved in adipose tissue inflammation in obesity. In obese rodents and humans, monocytes infiltrate adipose tissue and differentiate into proinflammatory macrophages [4]. In addition, subsets of $\mathrm{T}$ lymphocytes, including regulatory $\mathrm{T}$ cells [5], $\mathrm{CD}^{+}$effector $\mathrm{T}$ cells [6], and natural killer $\mathrm{T}$
C Biomed Central 
cells [7], are involved in adipose tissue inflammation in obesity.

In addition to their role in host defense, mast cells have been implicated in a variety of inflammatory and autoimmune diseases, such as allergic reactions, bullous pemphigoid, multiple sclerosis, inflammatory arthritis, and atherosclerosis [8]. Mast cells accumulate in the adipose tissue of obese human subjects and diet-induced obese mice [9-11]. Furthermore, mast cell deficiency and mast cell stabilizers are shown to diminish adverse metabolic effects of a high-fat diet [10]. Of note, we have shown that mast cells in the epididymal fat of dietinduced obese mice contain and secrete tumor necrosis factor- $\alpha$ (TNF- $\alpha$ ), a proinflammatory cytokine implicated in the pathogenesis of obesity [11].

There is a remarkable diversity in the structure and function of the adipose tissue found in different anatomical locations $[12,13]$. Whereas visceral adiposity is closely associated with adverse cardiovascular outcome, increased subcutaneous fat, especially around thighs and hips, poses little to no risk [14]. We recently demonstrated that macrophages and mast cells are distributed differentially in abdominal fat depots of both lean and diet-induced obese mice [11]. We also showed that dietinduced obesity in mice is associated with a marked increase in mast cells in the visceral, but not in the subcutaneous, fat depots [11]. Although adipose tissue inflammation in obesity and its metabolic sequelae have been the focus of intense research over the past two decades, little is known about immune responses that take place in regional lymph nodes draining inflamed adipose tissues. Lymph nodes are strategically located lymphoid tissues where innate immune responses result in adaptive immunity [15]. The involvement of lymphocytes in adipose tissue inflammation in obesity suggests a crosstalk between innate and adaptive immune systems in peripheral lymphoid tissues. Although there are many potential targets, we examined the effects of adipose tissue inflammation on mast cells in abdominal lymph nodes.

The present study explored whether obesity and insulin resistance as a result of leptin deficiency affect the density and distribution of mast cells in metabolic (abdominal fat depots, skeletal muscle, and liver) and lymphatic (abdominal lymph nodes, spleen, and thymus) organs. We also determined the prevalence of mast cells immunoreactive for TNF- $\alpha$ in epididymal and inguinal (subcutaneous) fat depots.

\section{Methods}

\section{Experimental animals}

We followed the 'Principles of laboratory animal care' established by the National Institutes of Health. The Institutional Animal Care and Use Committee of the
University of Miami approved all procedures on experimental animals (IACUC protocol number 08-245). Male leptin-deficient $(o b / o b, \mathrm{n}=10)$ and control $(+/ ?, \mathrm{n}=10)$ mice were purchased from the Jackson Laboratory (Bar Harbor, ME) and acclimated for three weeks before blood and tissue sampling was carried out at the age of 14 weeks. Mice were fed on a standard chow (Rodent Diet 5010, LabDiet, St. Louis, MO). Mice were weighed with a Scout Pro balance SP202 (Ohaus, Pine Brook, NJ). Organ weights were measured with a Sartorius ED124S Analytical Balance (Sartorius, Bohemia, NY).

\section{Glucose, insulin and cholesterol assays}

Blood was obtained from the tail of unanesthetized mice after overnight fasting for 15 hours. Blood glucose concentrations were measured using a Contour glucometer (Bayer, Tarrytown, NY). Serum insulin concentrations were measured by immunoassay following manufacturer's instructions (Crystal Chem, Downer Grover, IL). Serum cholesterol concentrations were determined using Cholesterol LiquiColor kit (Stanbio Laboratory, Boerne, TX). Homeostasis Model of Assessment-Insulin Resistance (HOMA-IR) was calculated using the formula: fasting glucose $(\mathrm{mg} / \mathrm{dl}) \times$ fasting insulin $(\mathrm{mU} / \mathrm{L}) / 405$.

\section{Harvesting abdominal fat depots and lymph nodes}

The anatomy of abdominal fat depots and lymph nodes are illustrated in Figure 1. Non-fasted mice were euthanized and partially skinned. The right inguinal fat depot harboring the inguinal lymph node was dissected. After harvesting the right epididymal fat depot, the attached testis and epididymis were dissected under a Nikon SMZ 1500 microscope (Nikon, Melville, NY). The small intestine, attached mesenteric fat, and mesenteric lymph nodes were removed in toto. The retroperitoneal organs, including kidneys, retroperitoneal fat depots and retroperitoneal lymph nodes, were dissected off posterior abdominal wall.

\section{Quantification of mast cells}

Tissues were fixed in Carnoy's solution and embedded in paraffin. Five micron-thick sections were cut, baked at $60^{\circ} \mathrm{C}$ for one hour, deparaffinized in xylene, and rehydrated in a graded ethanol series and water. To demonstrate mast cells, toluidine blue staining was carried out by briefly submerging tissue sections in $0.1 \%$ aqueous toluidine blue (Electron Microscopy Sciences, EMS, Hatfield, PA) [11]. Mast cells were counted in twenty highpower fields (400X) of toluidine blue-stained sections and their density was expressed as mast cells per $\mathrm{mm}^{2}$ of tissue section. In the epididymal fat, mast cells were counted along the long axis of the fat depot from rostral to caudal. In the mesenteric, perinephric, and inguinal subcutaneous fat depots, mast cells were counted in 


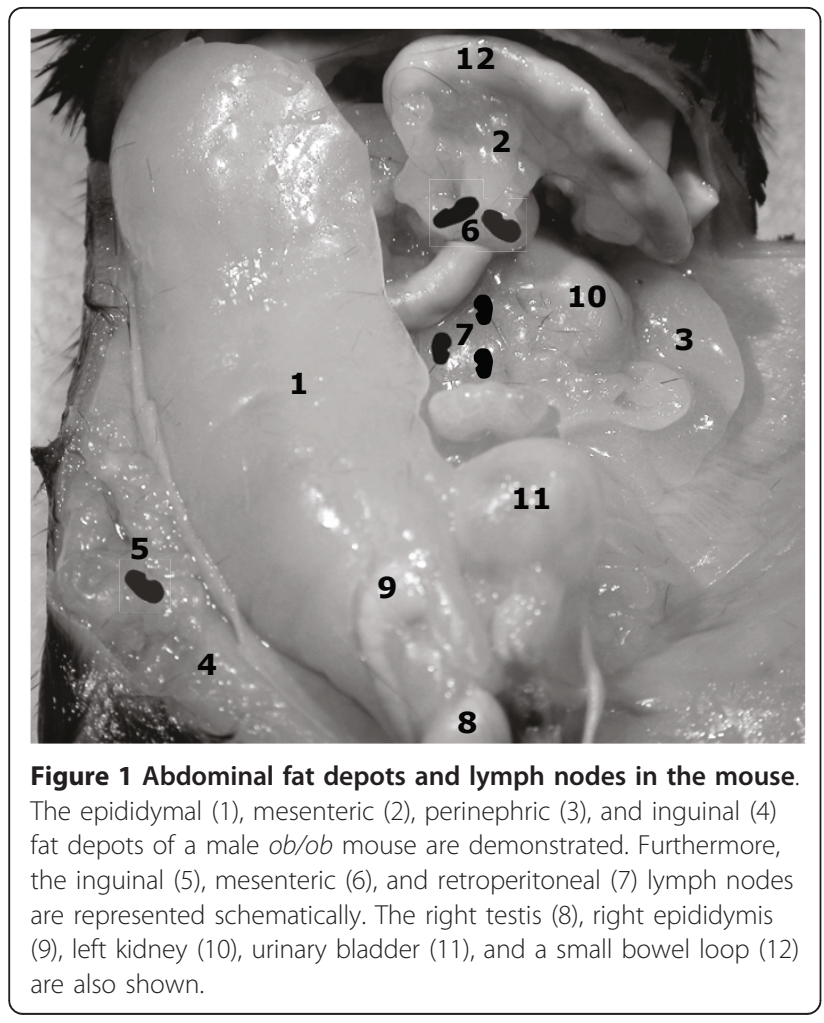

areas away from the mesenteric, retroperitoneal, and inguinal lymph nodes, respectively.

\section{Enzyme histochemistry}

Esterase activity of mast cells was demonstrated as previously described [11]. Briefly, tissue sections were stained with a mixture of new fuchsin acid solution (Poly Scientific, Bay Shore, NY), 4\% sodium nitrite solution (Sigma-Aldrich, St. Louis, MO), and naphthol AS-D chloroacetate solution (Sigma-Aldrich) in $0.1 \mathrm{M}$ sodium phosphate buffer, pH 7.6 (EMS) and counterstained with Mayer's hematoxylin (EMS). Light microscopic images were acquired using a Leica DMLB microscope with a Leica DFC420 C color camera (Leica, Bannockburn, IL).

\section{Immunofluorescence staining}

After blocking with 5\% goat serum, deparaffinized tissue sections were sequentially incubated with polyclonal rabbit anti-mouse TNF- $\alpha$ antibody (1:250; Abcam, Cambridge, MA) and Alexa Fluor 594-labeled goat anti-rabbit IgG (1:1000; Molecular Probes, Eugene, OR). Mast cells were labeled with FITC-conjugated avidin (1:100; BD Pharmingen, San Jose, CA) as previously described $[11,16]$.

\section{Protein extraction and immunoblotting}

Epididymal and inguinal adipose tissue $(100 \mathrm{mg})$ were homogenized in $0.5 \mathrm{ml}$ ice-cold lysis buffer containing $50 \mathrm{mM}$ Tris- $\mathrm{HCl}$ (pH 7.4), $150 \mathrm{mM} \mathrm{NaCl}, 1 \% \mathrm{NP}-40$,
0.5\% sodium deoxycholate, $0.1 \%$ SDS, $5 \mathrm{mM}$ EDTA, 1 mM EGTA (Boston BioProducts, Ashland, MA) supplemented with a cocktail of protease inhibitors (Complete Mini, Roche Applied Science, Indianapolis, IN). Following agitation on a rotator for 1 hour and centrifugation at $13,000 \mathrm{rpm}$ for 20 minutes at $4^{\circ} \mathrm{C}$, middle phase of lysate containing $30 \mu \mathrm{g}$ protein was subjected to polyacrylamide gel electrophoresis (NuPAGE Bis-Tris system, Invitrogen, Carlsbad, CA). A rabbit polyclonal antibody against CD117/c-kit (1:1000, Dako, Carpinteria, CA) and a mouse monoclonal antibody against actin (1:1000, Sigma-Aldrich) were used for immunoblotting.

\section{Statistics}

Results are presented as mean \pm SEM. Unpaired Student's t test was used to assess for statistically significant differences between groups. Comparisons among multiple groups were made using one-way analysis of variance (ANOVA) with Tukey post-hoc analysis. GraphPad Prism software (5.0a) was used for calculations (GraphPad Software, La Jolla, CA).

\section{Results}

Leptin-deficient $o b / o b$ mice demonstrated adiposity, insulin resistance, and hypercholesterolemia

Compared to controls, $o b / o b$ mice demonstrated greater body mass, fasting blood glucose, serum insulin and cholesterol concentrations, and HOMA-IR (Homeostatic model assessment-insulin resistance) (Table 1). In addition, $o b / o b$ mice had larger liver, inguinal and epididymal fat depots than control mice (Table 1).

\section{Mast cells were distributed differentially in abdominal fat depots}

Mast cells were present in abdominal fat depots of $o b /$ $o b$ and control mice (Figure 2). The density of mast cells, however, differed from one fat depot to another. In control mice, the density of mast cells was higher in subcutaneous than in visceral fat depots (Figures 2A-E). Moreover, the density of mast cells was 2.5 -fold higher in mesenteric and perinephric than in epididymal fat in

Table 1 Metabolic characteristics of mice

\begin{tabular}{cccc}
\hline Variables & ob/ob $(\mathbf{n}=\mathbf{1 0})$ & $+\mathbf{l}(\mathbf{n}=\mathbf{1 0})$ & $\boldsymbol{P}$ value \\
\hline Body weight $(\mathrm{g})$ & $60.2 \pm 1.2$ & $33.0 \pm 0.7$ & $<0.001$ \\
\hline Epididymal fat weight $(\mathrm{g})$ & $1.70 \pm 0.04$ & $0.41 \pm 0.05$ & $<0.001$ \\
\hline Inguinal fat weight $(\mathrm{g})$ & $1.86 \pm 0.07$ & $0.21 \pm 0.02$ & $<0.001$ \\
\hline Liver weight $(\mathrm{g})$ & $4.96 \pm 0.17$ & $1.53 \pm 0.06$ & $<0.001$ \\
\hline Blood glucose $(\mathrm{mg} / \mathrm{dl})$ & $115 \pm 8$ & $64 \pm 3$ & $<0.001$ \\
\hline Serum insulin $(\mathrm{ng} / \mathrm{ml})$ & $5.8 \pm 0.6$ & $1.1 \pm 0.2$ & $<0.001$ \\
\hline HOMA-IR & $47.2 \pm 4.9$ & $5.0 \pm 0.7$ & $<0.001$ \\
\hline Serum cholesterol $(\mathrm{mg} / \mathrm{dl})$ & $228 \pm 5$ & $89 \pm 4$ & $<0.001$ \\
\hline
\end{tabular}






control mice (Figure 2A). In $o b / o b$ mice, however, the density of mast cells was higher in epididymal fat than in inguinal, mesenteric, and perinephric fat depots (Figures $2 \mathrm{~F}-\mathrm{J})$.

Leptin deficiency led to a divergent change in the density of mast cells in inguinal and epididymal fat

Leptin deficiency-induced obesity was accompanied by a 20 -fold increase in the density of mast cells in epididymal fat, but a 13-fold decrease in inguinal fat (Figures $2 \mathrm{~K}-\mathrm{M})$. No statistically significant difference in the density of mast cells in mesenteric and perinephric fat depots between $o b / o b$ and control mice was observed (Figures $2 \mathrm{~N}, \mathrm{O}$ ). To confirm divergent alteration in the density of mast cells in epididymal vs. inguinal adipose tissue, tissue homogenates were subjected to immunoblotting for CD117/c-kit, a transmembrane tyrosine kinase receptor highly expressed in mast cells. Consistent with increased mast cell density in epididymal fat with leptin deficiency, Western blot analysis demonstrated increased CD117/c-kit expression (Figure 2P). A decline in mast cell density in inguinal fat with leptin 
deficiency was accompanied by diminished CD117/c-kit protein expression (Figure 2Q).

\section{The proportion of mast cells immunoreactive for TNF- $\alpha$} was higher in epididymal than in inguinal fat

We have previously shown that adipose tissue mast cells may be immunoreactive for TNF- $\alpha$ (11). Considering biological differences between subcutaneous and visceral fat, we tested whether the prevalence of mast cells immunoreactive for TNF- $\alpha$ was different between inguinal and epididymal fat. We found that $96 \%$ of mast cells in epididymal fat from control mice were immunoreactive for TNF- $\alpha$. However, only $69 \%$ of those in inguinal fat showed TNF- $\alpha$ immunoreactivity (Figure $3 \mathrm{~A})$. In $o b / o b$ mice, TNF- $\alpha$ immunoreactivity was also observed in the vast majority of mast cells (95\%) in epididymal fat, while only $53 \%$ of mast cells in inguinal fat were immunoreactive for TNF- $\alpha$ (Figure 3B). Therefore, the proportion of mast cells immunoreactive for TNF- $\alpha$ was greater in visceral than in subcutaneous fat in both $o b / o b$ and control mice.

\section{Mast cells were distributed differentially in abdominal lymph nodes}

Tissue inflammation often leads to immune responses in draining lymph nodes. Here, we sought to determine the effects of leptin deficiency-induced obesity on the density of mast cells residing in abdominal lymph nodes. We found that mast cells populated retroperitoneal, mesenteric, and inguinal lymph nodes in both $o b / o b$ and control mice (Figure 4). In control mice, the density of mast cells was significantly higher in retroperitoneal (40 \pm 12 cells $\left./ \mathrm{mm}^{2}\right)$ than in inguinal $\left(18 \pm 2\right.$ cells $\left./ \mathrm{mm}^{2}\right)$ and mesenteric $\left(0.1 \pm 0.1\right.$ cells $\left./ \mathrm{mm}^{2}\right)$ lymph nodes (Figures



Figure 3 TNF- $\alpha$ immunoreactivity in adipose tissue mast cells. Immunofluorescence microscopy demonstrated mast cells labeled with FITCconjugated avidin (green) and Alexa Fluor 594-labeled TNF- $\alpha$ (red) in epididymal and inguinal adipose tissues from control $(+/ ?, \mathrm{n}=5, \mathrm{white}$ bars, panel A) and ob/ob $\left(n=5\right.$, black bars, panel B) mice. Scale bars are $50 \mu \mathrm{m}$. ${ }^{*} P<0.05,{ }^{* *} P<0.01$. 


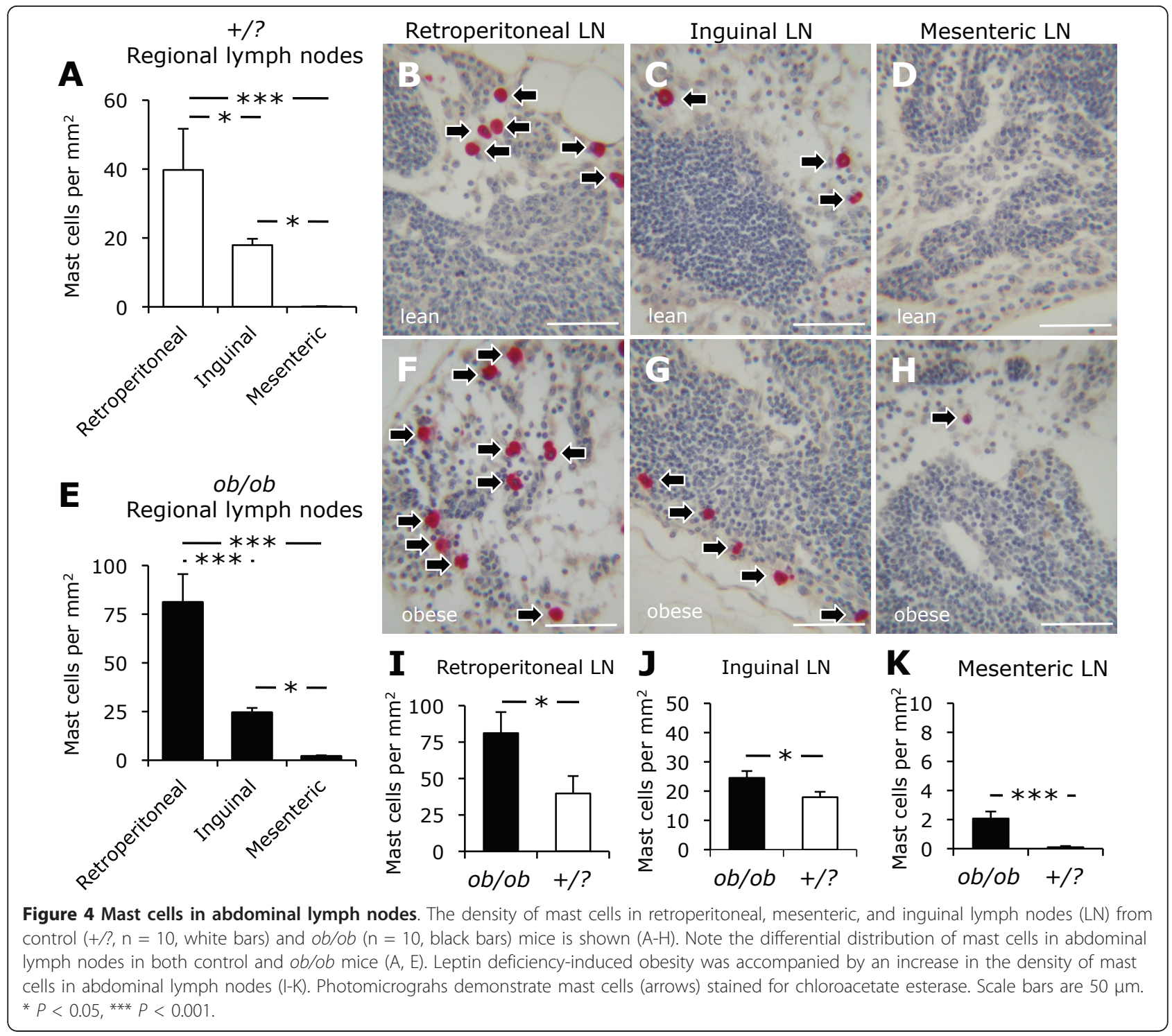

4A-D). Similarly, retroperitoneal lymph nodes had a higher density of mast cells $\left(81 \pm 14\right.$ cells $\left./ \mathrm{mm}^{2}\right)$ than inguinal $\left(25 \pm 2\right.$ cells $\left./ \mathrm{mm}^{2}\right)$ and mesenteric $(2.1 \pm 0.5$ cells $/ \mathrm{mm}^{2}$ ) lymph nodes in ob/ob mice (Figures $4 \mathrm{E}-\mathrm{H}$ ). In both $o b / o b$ and control mice, the density of mast cells was higher in inguinal than in mesenteric lymph nodes.

\section{Leptin deficiency-induced obesity was accompanied by} increased mast cell density in abdominal lymph nodes Mast cells were more prevalent in retroperitoneal, mesenteric, and inguinal lymph nodes from $o b / o b$ than those from control mice (Figures 4I-K). The density of mast cells in retroperitoneal lymph nodes was twofold higher in $o b / o b$ than in control mice (Figure 4I). Moreover, mast cells were $40 \%$ more prevalent in inguinal lymph node from $o b / o b$ mice than in that from control mice (Figure 4J). The density of mast cells in mesenteric lymph nodes was also higher in $o b / o b$ than in control mice (Figure $4 \mathrm{~K}$ ).

The density of mast cells in skeletal muscle, liver, spleen, and thymus was not affected by leptin deficiency

There was no significant difference in the density of mast cells in the gastrocnemius muscle between $o b / o b$ and control mice $\left(3.0 \pm 0.4\right.$ vs. $\left.2.1 \pm 0.2 \mathrm{cells} / \mathrm{mm}^{2}\right)$ (Figure 5A). Mast cells were rare in the liver of both $o b /$ $o b\left(0.02 \pm 0.02\right.$ cells $\left./ \mathrm{mm}^{2}\right)$ and control $(0.00 \pm 0.00$ cells $/ \mathrm{mm}^{2}$ ) mice (Figure $5 \mathrm{~B}$ ). The density of mast cells in the spleen of $o b / o b$ mice $\left(1.0 \pm 0.4\right.$ cells $\left./ \mathrm{mm}^{2}\right)$ was similar to that of controls $\left(1.2 \pm 0.5\right.$ cells $\left./ \mathrm{mm}^{2}\right)$ (Figure $5 \mathrm{C})$. Mast cells were rare in the thymus of both $o b / o b$ 

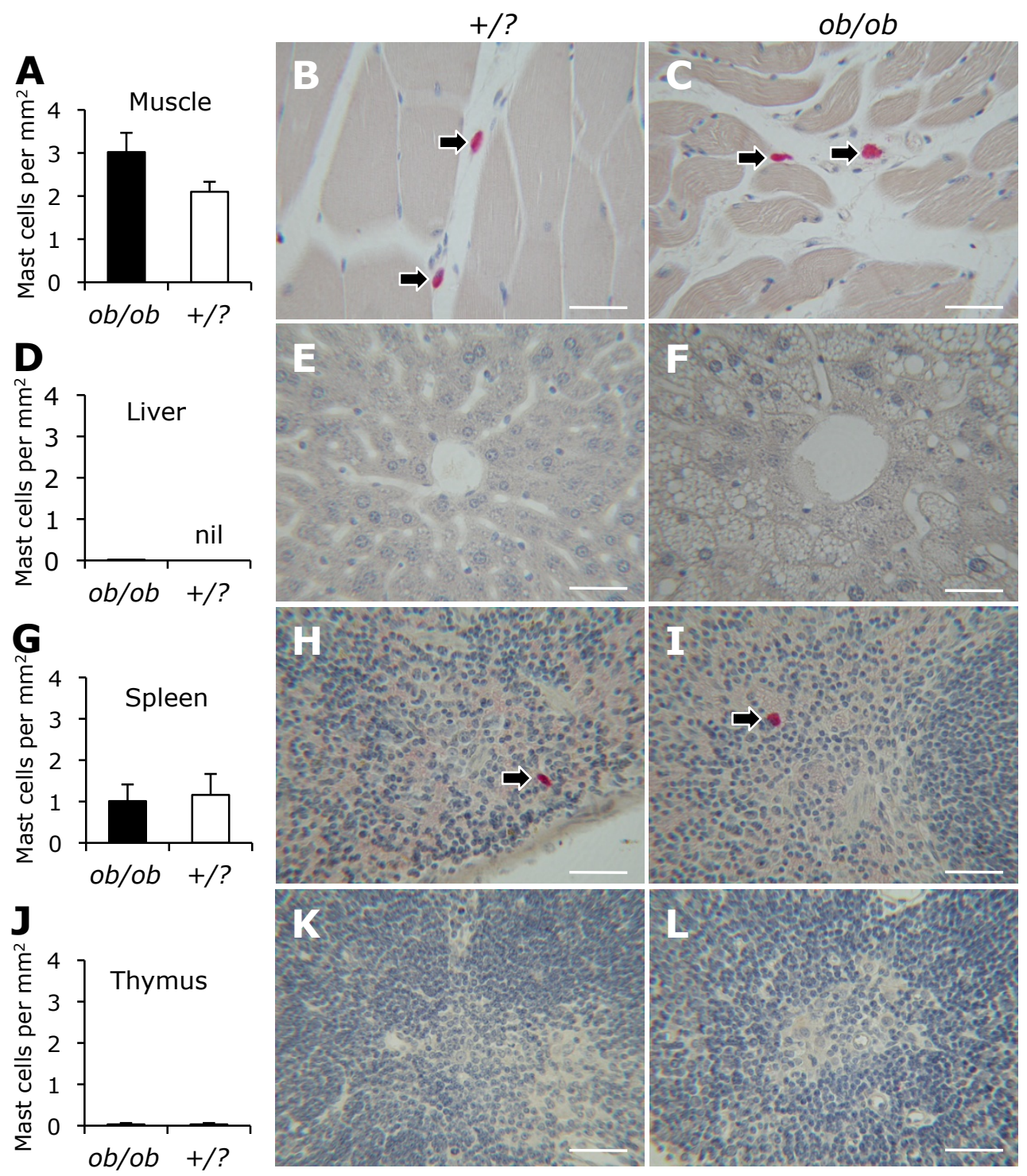

Figure 5 Mast cells in skeletal muscle, liver, spleen, and thymus. The density of mast cells in gastrocnemius muscle (A-C), liver (D-F), spleen $(\mathrm{G}-\mathrm{I})$, and thymus $(\mathrm{J}-\mathrm{L})$ from ob/ob $(\mathrm{n}=10$, black bars) and control $(+/$ ?, $\mathrm{n}=10$, white bars) mice is shown. Photomicrograhs demonstrate mast cells (arrows) stained for chloroacetate esterase. Scale bars are $50 \mu \mathrm{m}$.

$\left(0.03 \pm 0.03\right.$ cells $\left./ \mathrm{mm}^{2}\right)$ and control $(0.03 \pm 0.03$ cells $/$ $\mathrm{mm}^{2}$ ) mice (Figure 5D).

\section{Discussion}

Here, we demonstrated that mast cells are distributed differentially in abdominal fat depots and lymph nodes in leptin-deficient obese mice. With respect to abdominal fat depots, leptin deficiency-induced obesity was accompanied by a substantial increase (20-fold) in the density of mast cells in epididymal fat, while a remarkable decrease (11-fold) in the density of mast cells in inguinal (subcutaneous) fat was observed. This divergent alteration in the density of mast cells was confirmed by
CD117/c-kit protein expression analysis. Furthermore, the proportion of mast cells immunoreactive for TNF- $\alpha$ was significantly greater in epididymal than in inguinal fat. Leptin deficiency-induced obesity was associated with increased mast cells in abdominal lymph nodes. We found no significant difference in the density of mast cells in skeletal muscle, liver, spleen, and thymus between leptin deficient and control mice.

The structural and functional differences between fat depots in various anatomical locations have been the subject of much interest [12-14]. Since the discovery of adipose tissue inflammation in obesity and its impact on systemic insulin sensitivity, numerous studies have 
examined immune responses in fat depots in obese rodents and humans $[11,17,18]$. Our group recently reported that a high-fat diet (60\% calories from fat) fed for 20 weeks led to an increase in mast cells in epididymal (90-fold), perinephric (24-fold), and mesenteric (7fold) fat depots of 6-month-old C57BL/6 mice [11]. However, we found no significant difference in the density of mast cells in inguinal fat between diet-induced obese and control mice [11]. We believe that the differences observed between these two studies can be explained by at least three factors: 1) the duration of obesity; 2) the experimental diet; and 3) the proinflammatory properties of leptin, as discussed below.

Similar to other inflammatory diseases, adipose tissue inflammation in obesity is a dynamic pathophysiological process [18]. Neutrophils infiltrate visceral fat of mice within a week after high-fat feeding [19]. This is followed by macrophage accumulation and formation of crown-like structures [3,4]. Over time, adipose tissue inflammation in obesity is associated with collagen deposition and tissue fibrosis [18]. Thus, the type and severity of inflammatory changes in a specific fat depot is in part a function of the duration of obesity. Moreover, since fat depots have different propensity for obesity-associated inflammation, at any given time-point the severity of inflammation is different from one fat depot to another. In addition, the development of obesity and associated adipose tissue inflammation also depends on the type of diet consumed. We believe that a high-fat diet leads to more severe adipocyte injury and associated adipose tissue inflammation than the intake of larger quantities of a standard chow, as it is the case with leptin-deficient mice in the present study.

Pivotal in the regulation of energy homeostasis, metabolism, and neuroendocrine functions, leptin also plays an important role in innate and adaptive immune responses. Leptin can induce TNF- $\alpha$ and IL- 6 production by monocytes [20]. Leptin can also augment the ability of macrophages to phagocytize pathogens [21]. For example, macrophages harvested from leptin-deficient mice showed reduced phagocytosis of bacteria [22]. Since leptin is required for lymphopoiesis, leptin receptor-deficient mice have fewer circulating $\mathrm{B}$ - and $\mathrm{CD} 4^{+} \mathrm{T}$ lymphocytes and are unable to correct irradiationinduced lymphopenia [23]. By stimulating IL-2 and IFN- $\gamma$ and suppressing IL-4 production, Leptin may favor proinflammatory T-lymphocyte responses as well [24]. Leptin is also found to be important in the development and activation of natural killer cells [25]. Thus, a lower degree of adipose tissue inflammation in $o b / o b$ mice can also be accounted for by diminished innate and adaptive immune responses due to leptin deficiency.

A proinflammatory cytokine with diverse biological effects, TNF- $\alpha$ plays a critical role in the pathogenesis of obesity-linked insulin resistance [2]. Mast cells may contain preformed TNF- $\alpha$ [26]. Moreover, upon proper stimulation, TNF- $\alpha$ protein and gene expression can be upregulated in mast cells [26]. We have previously shown that mast cells in the epididymal fat of diet-induced obese mice store and secrete TNF- $\alpha$ [11]. Here we showed that the majority of mast cells in epididymal and subcutaneous adipose tissue of both leptin-deficient obese and control mice are immunoreactive for TNF- $\alpha$. However, we found that the proportion of mast cells immunoreactive for TNF- $\alpha$ was significantly higher in epididymal than in subcutaneous adipose tissue. Although other inflammatory and non-inflammatory cells in adipose tissue are capable of expressing TNF- $\alpha$, a lower proportion of mast cells immunoreactive for TNF$\alpha$ might be an important mechanism for the resilience of subcutaneous adipose tissue to metabolic challenges and consequent adipose tissue inflammation in obesity.

Lymph nodes are strategically located lymphoid tissues where innate immune responses can result in the induction of adaptive immunity [12]. Macrophages, B- and Tlymphocytes form the bulk of a lymph node. Although lymph nodes are involved in most immune responses, little is known about immunological reactions occurring in regional lymph nodes draining fat depots in obesity. A recent report indicated that increased T-lymphocyte activation and apoptosis was associated with decreased numbers of $\mathrm{CD}^{+}$and $\mathrm{CD} 8^{+} \mathrm{T}$-lymphocytes in mesenteric lymph nodes of diet-induced obese mice [27]. Moreover, decreased proportions of $\mathrm{CD}^{+} \mathrm{T}$-lymphocytes and higher proportions of helper $\mathrm{T}$-cell subsets in mesenteric lymph nodes of genetically obese rats compared to lean controls [28].

Mast cells are scattered in the cortical and medullary sinuses of murine lymph nodes [29]. While much is known about immune responses that take place in a lymph node, the immunological functions of mast cells in a lymph node remain largely elusive. It has been shown that mast cells residing in a lymph node can facilitate recruitment of T-lymphocytes by secreting chemokines such as macrophage inflammatory protein-1B [30]. Furthermore, mast cells in inflamed tissues can cause enlargement and activation of a draining lymph node by releasing TNF- $\alpha$ that is transported to draining lymph nodes [31]. In addition, it has been shown that dermal mast cells can migrate to draining lymph nodes and induce adaptive immune responses [30,32]. The present study is the first to show an increase in the density of mast cells in regional lymph nodes draining abdominal fat depots in obesity. The increased numbers of mast cells in the abdominal lymph nodes could be due to 1) increased mitotic activity of resident mast cells, 2) enhanced recruitment of precursor cells, 3) immigration from inflamed adipose tissue, and/or 4) 
decreased emigration. Although the contributions of mast cells to the activation of the immune system are widely recognized, under certain conditions mast cells can suppress immune responses [33]. Thus, further studies are required to delineate the role of mast cells in the lymph nodes draining inflamed fat depots in obesity.

The present study describes the effects of leptin deficiency-induced obesity on the distribution of mast cells in subcutaneous and visceral fat depots and regional lymph nodes. Important differences were noted between subcutaneous and epididymal fat depots. Increased density of mast cells in abdominal lymph nodes in obesity represents an anatomical link between adipose tissue inflammation and adaptive immune responses in lymph nodes. This work will stimulate design and implementation of mechanistic studies addressing immunological functions of mast cells in adipose and secondary lymphoid tissues in obesity.

\section{Abbreviations}

TNF-a: tumor necrosis factor-a; LN: lymph node.

\section{Acknowledgements}

This work was made possible by generous funds from the Katz Family Foundation. We are indebted to Christian Faul and George McNamara at the University of Miami for critically reviewing the manuscript.

\section{Author details}

${ }^{1}$ Department of Medicine, Miller School of Medicine, University of Miami, Miami, FL, USA. ²Diabetes Research Institute, University of Miami, Miami, FL, USA. ${ }^{3}$ Bascom Palmer Eye Institute, Department of Ophthalmology, University of Miami, Coral Gables, FL, USA. ${ }^{4}$ College of Engineering, University of Miami, Coral Gables, FL, USA. ${ }^{5}$ Department of Surgery, Miller School of Medicine, University of Miami, Miami, FL, USA.

\section{Authors' contributions}

MMA, BN, ECW, KBJ, GG, LMO researched data. MMA, JR, ND reviewed/ edited manuscript. AN designed experiments, researched data, and wrote manuscript. All authors' read and approved the final manuscript.

\section{Competing interests}

The authors declare that they have no competing interests.

Received: 31 December 2011 Accepted: 7 February 2012 Published: 7 February 2012

\section{References}

1. Mokdad AH, Ford ES, Bowman BA, Dietz WH, Vinicor F, Bales VS, Marks JS: Prevalence of obesity, diabetes, and obesity-related health risk factors. JAMA 2001, 289:76-79.

2. Hotamisligil GS: Inflammation and metabolic disorders. Nature 2006, 444:860-867.

3. Cinti S, Mitchell G, Barbatelli G, Murano I, Ceresi E, Faloia E, Wang S, Fortier M, Greenberg AS, Obin MS: Adipocyte death defines macrophage localization and function in adipose tissue of obese mice and humans. $J$ Lipid Res 2005, 46:2347-2355.

4. Xu H, Barnes GT, Yang Q, Tan G, Yang D, Chou CJ, Sole J, Nichols A, Ross JS, Tartaglia LA, Chen H: Chronic inflammation in fat plays a crucial role in the development of obesity-related insulin resistance. J Clin Invest 2003, 112:1821-1830.

5. Feuerer M, Herrero L, Cipolletta D, Naaz A, Wong J, Nayer A, Lee J, Goldfine AB, Benoist C, Shoelson S, Mathis D: Lean, but not obese, fat is enriched for a unique population of regulatory $T$ cells that affect metabolic parameters. Nat Med 2009, 15:930-939.
6. Nishimura S, Manabe I, Nagasaki M, Eto K, Yamashita H, Ohsugi M, Otsu M, Hara K, Ueki K, Sugiura S, Yoshimura K, Kadowaki T, Nagai R: CD8+ effector $T$ cells contribute to macrophage recruitment and adipose tissue inflammation in obesity. Nat Med 2009, 15:914-920.

7. Ohmura K, Ishimori N, Ohmura Y, Tokuhara S, Nozawa A, Horii S, Andoh Y, Fujii S, Iwabuchi K, Onoé K, Tsutsui H: Natural killer T cells are involved in adipose tissues inflammation and glucose intolerance in diet-induced obese mice. Arterioscler Thromb Vasc Biol 2010, 30:93-199.

8. Kalesnikoff J, Galli SJ: New developments in mast cell biology. Nat Immunol 2008, 9:1215-1223.

9. Hristova M, Aloe L, Ghenev PI, Fiore M, Chaldakov GN: Leptin and mast cells: a novel adipoimmune link. Turk J Med Sci 2001, 31:581-583.

10. Liu J, Divoux A, Sun J, Zhang J, Clément K, Glickman JN, Sukhova GK, Wolters PJ, Du J, Gorgun CZ, Doria A, Libby P, Blumberg RS, Kahn BB, Hotamisligil GS, Shi GP: Genetic deficiency and pharmacological stabilization of mast cells reduce diet-induced obesity and diabetes in mice. Nat Med 2009, 15:940-945.

11. Altintas MM, Azad A, Nayer B, Contreras G, Zaias J, Faul C, Reiser J, Nayer A: Mast cells, macrophages, and crown-like structures distinguish subcutaneous from visceral fat in mice. J Lipid Res 2011, 52:480-488.

12. Trayhurn P: Endocrine and signalling role of adipose tissue: new perspectives on fat. Acta Physio/ Scand 2005, 184:285-293.

13. Kissebah $\mathrm{AH}$, Krakower GR: Regional adiposity and morbidity. Physiol Rev 1994, 74:761-811.

14. Wajchenberg BL: Subcutaneous and visceral adipose tissue: their relation to the metabolic syndrome. Endocr Rev 2000, 21:697-738.

15. Von Andrian UH, Mempel TR: Homing and cellular traffic in lymph nodes. Nat Rev Immunol 2003, 3:867-878

16. Tharp MD, Seelig LL Jr, Tigelaar RE, Bergstresser PR: Conjugated avidin binds to mast cell granules. J Histochem Cytochem 1985, 33:27-32.

17. Murano I, Barbatelli G, Parisani V, Latini C, Muzzonigro G, Castellucci M, Cinti S: Dead adipocytes, detected as crown-like structures, are prevalent in visceral fat depots of genetically obese mice. J Lipid Res 2008, 49:1562-1568.

18. Strissel KJ, Stancheva Z, Miyoshi H, Perfield JW, DeFuria J, Jick Z Greenberg AS, Obin MS: Adipocyte death, adipose tissue remodeling, and obesity complications. Diabetes 2007, 56:2910-2918.

19. Elgazar-Carmon V, Rudich A, Hadad N, Levy R: Neutrophils transiently infiltrate intra-abdominal fat early in the course of high-fat feeding. $J$ Lipid Res 2008, 49:1894-1903.

20. Zarkesh-Esfahani H, Pockley G, Metcalfe RA, Bidlingmaier M, Wu Z, Ajami A, Weetman AP, Strasburger CJ, Ross RJ: High-dose leptin activates human leukocytes via receptor expression on monocytes. J Immunol 2001, 167:4593-4599.

21. Gainsford T, Willson TA, Metcalf D, Handman E, McFarlane C, Ng A, Nicola NA, Alexander WS, Hilton DJ: Leptin can induce proliferation, differentiation, and functional activation of hemopoietic cells. Proc Natl Acad Sci USA 1996, 93:14564-14568.

22. Mancuso P, Gottschalk A, Phare SM, Peters-Golden M, Lukacs NW, Huffnagle GB: Leptin-deficient mice exhibit impaired host defense in Gram-negative pneumonia. J Immunol 2002, 168:4018-4024.

23. Bennett BD, Solar GP, Yuan JQ, Mathias J, Thomas GR, Matthews W: A role for leptin and its cognate receptor in hematopoiesis. Curr Biol 1996 6:1170-1180.

24. Lord GM, Matarese G, Howard JK, Baker RJ, Bloom SR, Lechler Rl: Leptin modulates the T-cell immune response and reverses starvation-induced immunosuppression. Nature 1998, 394:897-901.

25. Tian Z, Sun R, Wei H, Gao B: Impaired natural killer (NK) cell activity in leptin receptor deficient mice: leptin as a critical regulator in NK cell development and activation. Biochem Biophys Res Commun 2002, 298:297-302.

26. Gordon JR, Galli SJ: Mast cells as a source of both preformed and immunologically inducible TNF-alpha/cachectin. Nature 1990, 346:274-276

27. Kim CS, Lee SC, Kim YM, Kim BS, Choi HS, Kawada T, Kwon BS, Yu R: Visceral fat accumulation induced by a high-fat diet causes the atrophy of mesenteric lymph nodes in obese mice. Obesity 2008, 16:1261-1269.

28. Blewett HJ, Gerdung CA, Ruth MR, Proctor SD, Field CJ: Vaccenic acid favourably alters immune function in obese JCR:LA-cp rats. Br J Nutr 2009, 102:526-536. 
29. Majeed SK: Mast cell distribution in mice. Arzneimittelforschung 1994, 44:1170-1173.

30. Wang HW, Tedla N, Lloyd AR, Wakefield D, McNeil PH: Mast cell activation and migration to lymph nodes during induction of an immune response in mice. J Clin Invest 1998, 102:1617-1626.

31. McLachlan JB, Hart JP, Pizzo SV, Shelburne CP, Staats HF, Gunn MD, Abraham SN: Mast cell-derived tumor necrosis factor induces hypertrophy of draining lymph nodes during infection. Nat Immunol 2003, 4:1199-1205.

32. Byrne SN, Limón-Flores AY, Ullrich SE: Mast cell migration from the skin to the draining lymph nodes upon ultraviolet irradiation represents a key step in the induction of immune suppression. J Immunol 2008, 180:4648-4655.

33. Galli SJ, Grimbaldeston M, Tsai M: Immunomodulatory mast cells: negative, as well as positive, regulators of immunity. Nat Rev Immunol 2008, 8:478-486.

doi:10.1186/1476-511X-11-2

Cite this article as: Altintas et al: Leptin deficiency-induced obesity affects the density of mast cells in abdominal fat depots and lymph nodes in mice. Lipids in Health and Disease 2012 11:21.

\section{Submit your next manuscript to BioMed Central} and take full advantage of:

- Convenient online submission

- Thorough peer review

- No space constraints or color figure charges

- Immediate publication on acceptance

- Inclusion in PubMed, CAS, Scopus and Google Scholar

- Research which is freely available for redistribution

Submit your manuscript at www.biomedcentral.com/submit 